\title{
PENGEMBANGAN SISTEM INFORMASI PANDUAN MITIGASI BENCANA ALAM PROVINSI SUMATERA BARAT BERBASIS ANDROID
}

\author{
Fadel Muhammad ${ }^{1}$ \\ Ahmaddul Hadi ${ }^{2}$ \\ Dedy Irfan $^{3}$
}

\begin{abstract}
West Sumatera is one of the provinces in Indonesia which, when viewes from a potential disaster based on BNPB data, is a region with a high hazard potential. Disaster can happen anytime and anywhere so people need to increase alertness, awareness, and preparedness commonly called disaster response society. Along with the rapid advancement of mobile technology, an application is required that accommodates the needs of the community for applications that can provide up-to-date information about disater mitigation effectively and efficiently. The purpose of this final project is to develop a natural disaster information guide system that can assist people in finding information about disaster mitigation guidelines, news \& mitigation events, disaster reporting \& disaster questioning services, and provide BPBD location and evacuation routes using Google Map API. This final project resulted in a system of natural disaster mitigation guidance information in the form of a website on the server and android application on the client that use the $U M L$ modeling. The manufacturing process on the server using PHP, HTML, CSS, Javascript programming language based on Codelgniter framework with MYSQL as DBMS and Sublimetext3 as editor, while the client uses Java programming language with Android Studio as IDE. A natural disaster mitigation guidance system can help BPBD has been created can assist BPBD in educating and improving services to the community in terms of disaster mitigation especially in West Sumatera province. Then make it easier to the society in accessing information about the mitigation of natural disasters.
\end{abstract}

Keywords : Disaster, Mitigation, Client-Server, Codelgniter, Java, Android

\footnotetext{
${ }^{1}$ Jurusan Teknik Elektronika UNP

2. Dosen Jurusan Teknik Elektronika UNP

${ }^{3 .}$ Dosen Jurusan Teknik Elektronika UNP
} 


\section{INTI SARI}

Sumatera Barat adalah salah satu provinsi di Indonesia yang bila dilihat dari potensi bencana berdasarkan data BNPB, adalah wilayah dengan potensi bahaya yang tinggi. Bencana dapat terjadi kapan saja dan di mana saja sehingga orang perlu meningkatkan kewaspadaan, kesadaran, dan kesiapan yang biasa disebut masyarakat tanggap bencana. Seiring dengan pesatnya kemajuan teknologi seluler, diperlukan aplikasi yang mengakomodasi kebutuhan masyarakat untuk aplikasi yang dapat memberikan informasi terkini tentang mitigasi disater secara efektif dan efisien. Tujuan dari proyek akhir ini adalah untuk mengembangkan sistem panduan informasi bencana alam yang dapat membantu orang dalam mencari informasi tentang panduan mitigasi bencana, berita \& peristiwa mitigasi, pelaporan bencana \& layanan pertanyaan bencana, dan menyediakan lokasi BPBD dan rute evakuasi menggunakan Google Map API. Tugas akhir ini menghasilkan sistem informasi panduan mitigasi bencana alam berupa situs web pada server dan aplikasi android pada klien yang menggunakan pemodelan UML. Proses pembuatan pada server menggunakan PHP, HTML, CSS, bahasa pemrograman Javascript berdasarkan kerangka Codelgniter dengan MYSQL sebagai DBMS dan Sublimetext3 sebagai editor, sedangkan klien menggunakan bahasa pemrograman Java dengan Android Studio sebagai IDE. Sebuah sistem panduan mitigasi bencana alam dapat membantu BPBD telah dibuat dapat membantu BPBD dalam mendidik dan meningkatkan layanan kepada masyarakat dalam hal mitigasi bencana terutama di provinsi Sumatera Barat. Kemudian mempermudah masyarakat dalam mengakses informasi tentang mitigasi bencana alam.

Kata Kunci : Bencana, Mitigasi, Server-Klien, Codelgniter, Java, Android 


\section{PENDAHULUAN}

Menurut Undang-undang No. 24 Tahun 2007 tentang Penanggulangan Bencana menyebutkan bahwa pengertian Bencana adalah peristiwa atau rangkaian peristiwa yang mengancam dan mengganggu kehidupan dan penghidupan masyarakat yang disebabkan, baik oleh faktor alam dan/ atau faktor non-alam maupun faktor manusia sehingga mengakibatkan timbulnya korban jiwa manusia, kerusakan lingkungan, kerugian harta benda dan bencana sosial.

Seiring dengan
berkembangnya waktu dan
meningkatnya aktivitas manusia,
kerusakan lingkungan hidup
cenderung semakin parah dan
memicu meningkatnya jumlah
kejadian bencana hidrometeorologi
seperti banjir, tanah longsor,
kebakaran hutan dan kekeringan
yang terjadi secara silih berganti di
banyak daerah Indonesia khususnya
di Provinsi Sumatera Barat.

Sumatera Barat adalah salah satu provinsi di Indonesia yang terletak di Pulau Sumatera. Dilihat dari potensi bencana berdasarkan data BNPB, Provinsi Sumatera Barat merupakan wilayah dengan potensi bahaya (hazard potency) yang tinggi. Beberapa potensi bencana yang mengancam antara lain adalah gempa bumi, tsunami, banjir, letusan gunung api, abrasi pantai, kekeringan, cuaca ekstrim, tanah longsor, angin ribut, kebakaran hutan dan lahan.Potensi bencana tersebut mengancam hampir seluruh Kabupaten dan Kota di Provinsi Sumatera Barat yang disajikan pada tabel 1.

Seringkali penyebab tingginya jumlah korban jiwa dan materi akibat bencana alam adalah kurangnya panduan dan pemahaman masyarakat terhadap mitigasi bencana maupun karakteristik ancaman (hazards) yang berpotensi terjadi di daerahnya masing-masing. Kemudian kurangnya informasi/ peringatan dini (early warning) dan kesulitan untuk bertanya langsung kepada petugas BPBD mengenai pertanyaan seputar bencana yang menyebabkan ketidaksiapan dan ketidakmampuan dalam menghadapi bencana yang berasal dari lingkungannya.

Tabel 1. Indeks Risiko Bencana per Kabupaten/Kota Prov. Sumatera Barat
\begin{tabular}{|l|l|l|l|c|c|}
\hline \multirow{2}{*}{ No. } & \multirow{2}{*}{ Kabupaten / Kota } & \multicolumn{2}{|c|}{ IRBI 2013} & \multicolumn{2}{c|}{ PIRBI 2016} \\
\cline { 3 - 6 } & Skor & $\begin{array}{c}\text { Kelas } \\
\text { Risiko }\end{array}$ & Skor & Kelas Resiko \\
\hline 1 & Kota Padang & 209 & Tinggi & 209,2 & Tinggi \\
\hline 2 & Agam & 209 & Tinggi & 209 & Tinggi \\
\hline 3 & Pasaman Barat & 203 & Tinggi & 203 & Tinggi \\
\hline 4 & Kepulauan Mentawai & 197 & Tinggi & 197,2 & Tinggi \\
\hline 5 & Padang Pariaman & 197 & Tinggi & 196,8 & Tinggi \\
\hline 6 & Pesisir Selatan & 190 & Tinggi & 190 & Tinggi \\
\hline 7 & Pasaman & 178 & Tinggi & 178 & Tinggi \\
\hline 8 & Kota Pariaman & 171 & Tinggi & 171 & Tinggi \\
\hline 9 & Dharmasraya & 143 & Sedang & 143 & Sedang \\
\hline 10 & Solok & 137 & Sedang & 137 & Sedang \\
\hline 11 & Solok Selatan & 137 & Sedang & 137 & Sedang \\
\hline 12 & Kota Bukitinggi & 130 & Sedang & 130 & Sedang \\
\hline 13 & Tanah Datar & 125 & Sedang & 125 & Sedang \\
\hline 14 & Kota Solok & 125 & Sedang & 125 & Sedang \\
\hline 15 & Lima Puluh Kota & 119 & Sedang & 119 & Sedang \\
\hline 16 & Kota Padang Panjang & 113 & Sedang & 113 & Sedang \\
\hline 17 & Kota Sawahlunto & 113 & Sedang & 113 & Sedang \\
\hline 18 & Sijunjung & 107 & Sedang & 107 & Sedang \\
\hline 19 & Kota Payakumbuh & 105 & Sedang & 105 & Sedang \\
\hline
\end{tabular}
(Sumber: Indeks Resiko Bencana Indonesia BNPB, 2013 dan Penurunan Indeks

Resiko Bencana Indonesia BNPB, 2016)

Tentu saja upaya yang selama ini dilakukan Pemerintah melalui BPBD belum maksimal. Media penyebaran informasi seputar panduan mitigasi bencana seperti buku, selebaran, spanduk/baliho dan rambu-rambu dapat rusak, hancur dan hilang bila tidak dirawat dengan baik. Sehingga dibutuhkan sebuah terobosan guna mensosialisasikan dan memasyarakatkan pembelajaran mitigasi bencana yang sangat berguna pada saat bencana.

Salah satu media komunikasi yang dapat digunakan adalah smartphone android. Android memiliki sejumlah kelebihan seperti kemampuan Multi-Tasking, notification untuk memudahkan mengakses informasi, memiliki 
tampilan grafis yang indah, nyaman digunakan untuk browsing, menyediakan berbagai aplikasi menarik dan gratis. Platform android telah berkembang pesat dari segi teknologi maupun dari segi jumlah device, sehingga masyarakat luas dari segala usia lebih memilih menggunakan smartphone android.

Adapun maksud dan tujuan dari tugas akhir ini adalah: 1) Mengembangkan Sistem Informasi dengan memanfaaatkan bahasa pemrograman PHP menggunakan framework Codeigniter pada pengembangan server dan bahasa pemrograman Java pada pengembangan client; 2) Menghasilkan Sistem Informasi yang dapat membantu sekaligus meng-edukasi masyarakat dalam hal panduan mitigasi bencana, berita artikel \& event mitigasi dan layanan interaksi Lapor Bencana \& Tanya Bencana serta memberikan peta petunjuk lokasi BPBD dan Jalur evakuasi menggunakan Google Map API.; 3) Menerapkan paradigma ClientServer pada pengembangan aplikasi, dimana website sebagai aplikasi server dan platform Android sebagai aplikasi client.

\section{ANALISIS \& PERANCANGAN SISTEM}

\section{Analisis Sistem}

Analisis sistem adalah penguraian dari suatu sistem yang utuh ke dalam bagianbagian komponennya dengan maksud untuk mengidentifikasi dan mengevaluasi permasalahan. Analisis sistem terdiri dari dua komponen yaitu analisis yang sedang berjalan dan analisis yang diusulkan. Beberapa komponen analisis sistem sebagai berikut:
a. Analisis yang sedang berjalan
Analisis sistem yang berjalan menjelaskan bagai-

mana gambaran terhadap sistem yang berjalan saat ini, yang meliputi diantaranya: Analisis proses bisnis, analisis aturan bisnis, analisis pelaku, analisis masalah dan solusi, serta flow-map yang sedang berjalan saat ini.

b. Analisis yang diusulkan

$\begin{array}{lr}\text { Analisis } & \text { sistem yang } \\ \text { diusulkan } & \text { menjelaskan } \\ \text { bagaimana } & \text { gambaran }\end{array}$ terhadap sistem yang akan diusulkan untuk dikembangkan guna menyelesaikan permasalahan yang sedang berjalan saat ini, yang meliputi diantaranya: Analisis User, yang terdiri dari user server dan client, Analisis Proses dan Prosedur; Analisis dokumen $\mathrm{I} / \mathrm{O}$, yang terdiri dari dokumen I/O pada server dan client; Analisis persyaratan fungsional dan non-fungsional; serta flowmap yang akan diusulkan.

\section{Perancangan Sistem}

Perancangan sistem dilakukan untuk menggambarkan dan merencanakan, dari beberapa elemen yang terpisah ke dalam satu kesatuan yang utuh dan berfungsi serta hasil transformasi dari analisis ke dalam perancangan yang nantinya akan diimplementasikan. Beberapa komponen analisis sistem diantaranya:

a. Context Diagram

Context Diagram merupakan tingkatan tertinggi dalam diagram alur data dan menunjukan sistem secara keseluruhan serta menggambarkan secara jelas mengenai ruang lingkup dari sistem yang dikembangkan. Berikut ini adalah perancangan 
context diagram pada server dan client.

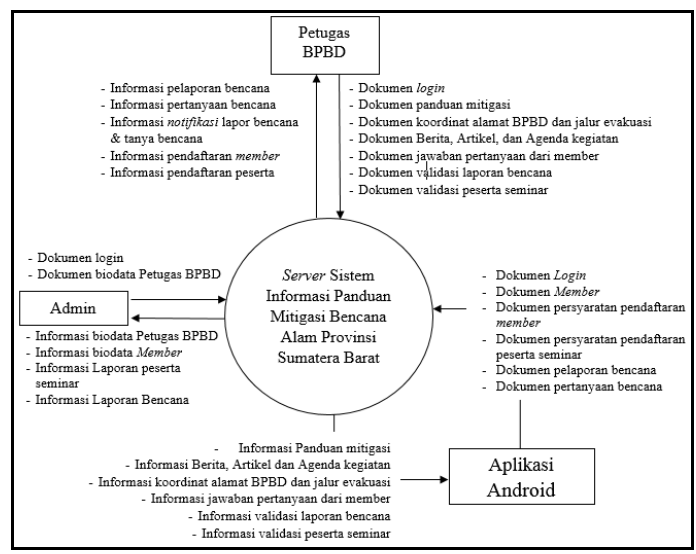

Gambar 1. Diagram Context pada Server

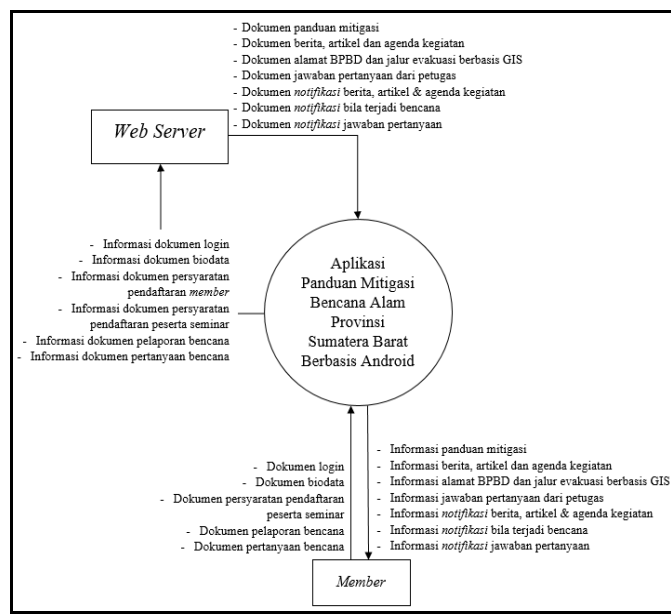

Gambar 2. Diagram Context pada Client

\section{b. Use Case Diagram}

Use Case diagram merupakan gambaran skenario dari interaksi yang menggambarkan hubungan antara aktor dan kegiatan yang dapat dilakukannya terhadap aplikasi. Aplikasi ini melibatkan 3 aktor yaitu Admin, Petugas, dan member. Terdapat dua bagian use case diagram yang dirancang untuk sistem yaitu perancangan use case server dan client. Berikut ini adalah gambar perancangan use case diagram:

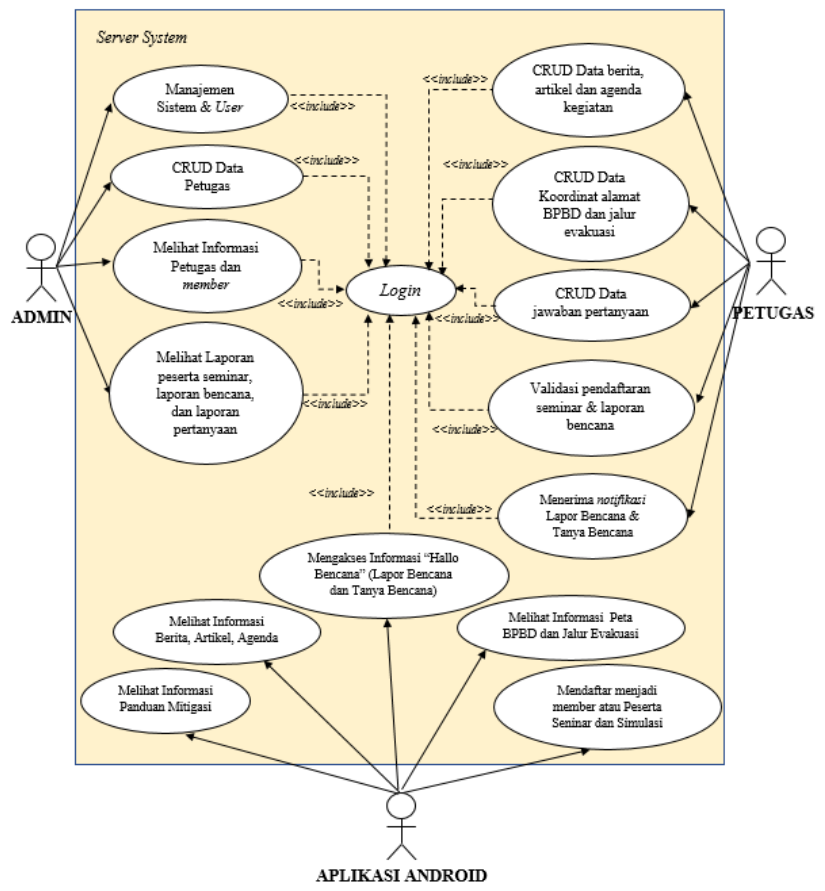

Gambar 3. Use case Diagram pada Server

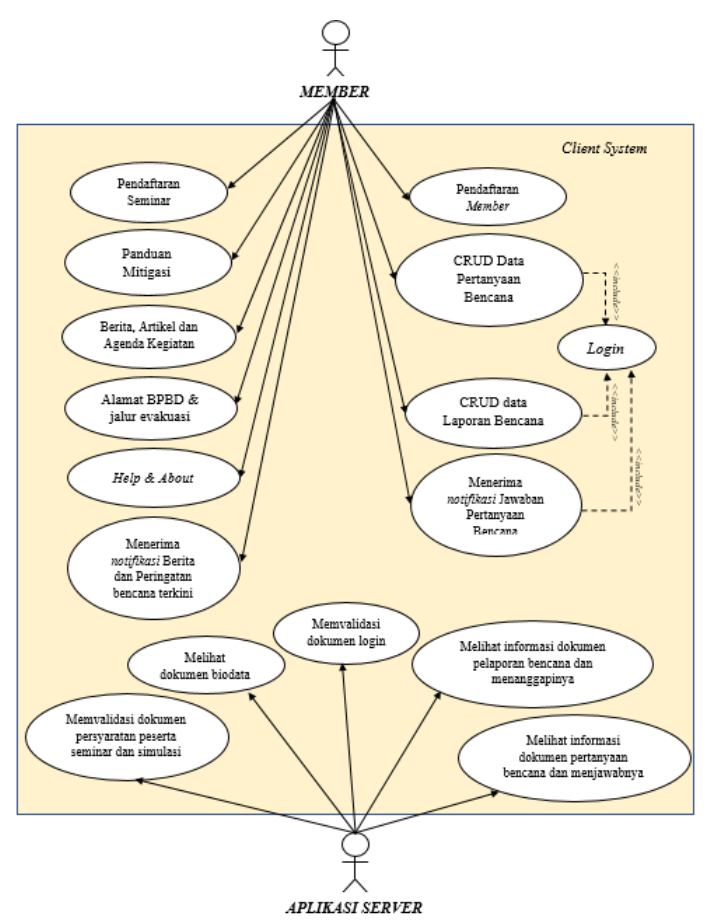

Gambar 4. Use case Diagram pada Client

c. Activity Diagram

Activity diagram memodelkan workflow proses bisnis dan urutan aktivitas dalam sebuah proses. 
Diagram ini sangat mirip dengan flowchart karena memodelkan workflow dari satu aktivitas ke aktivitas lainnya. Berikut ini adalah salah satu gambar perancangan activity diagram pada server dan client.

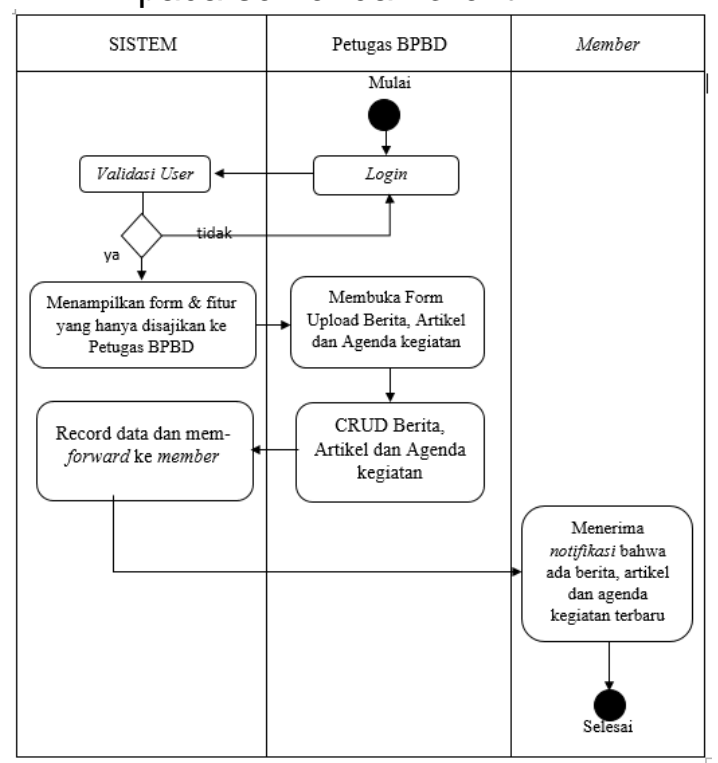

Gambar 5. Activity Diagram CRUD Berita, Artikel, dan Event

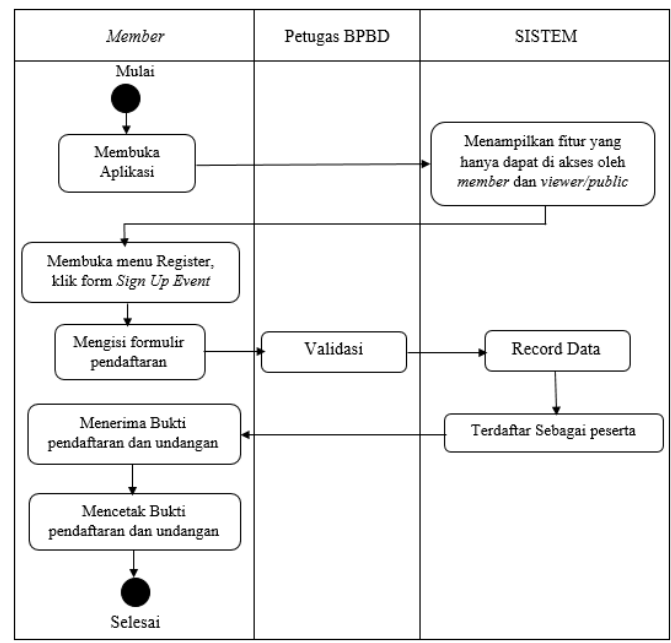

Gambar 6. Activity Diagram Pendaftaran Event

\section{d. Sequence Diagram}

Sequence

diagram

digunakan untuk menggambarkan proses yang

dilakukan oleh pengguna (user) terhadap sistem. Pada sistem ini terdapat beberapa sequence diagram pada server dan client, diantaranya sebagai berikut:

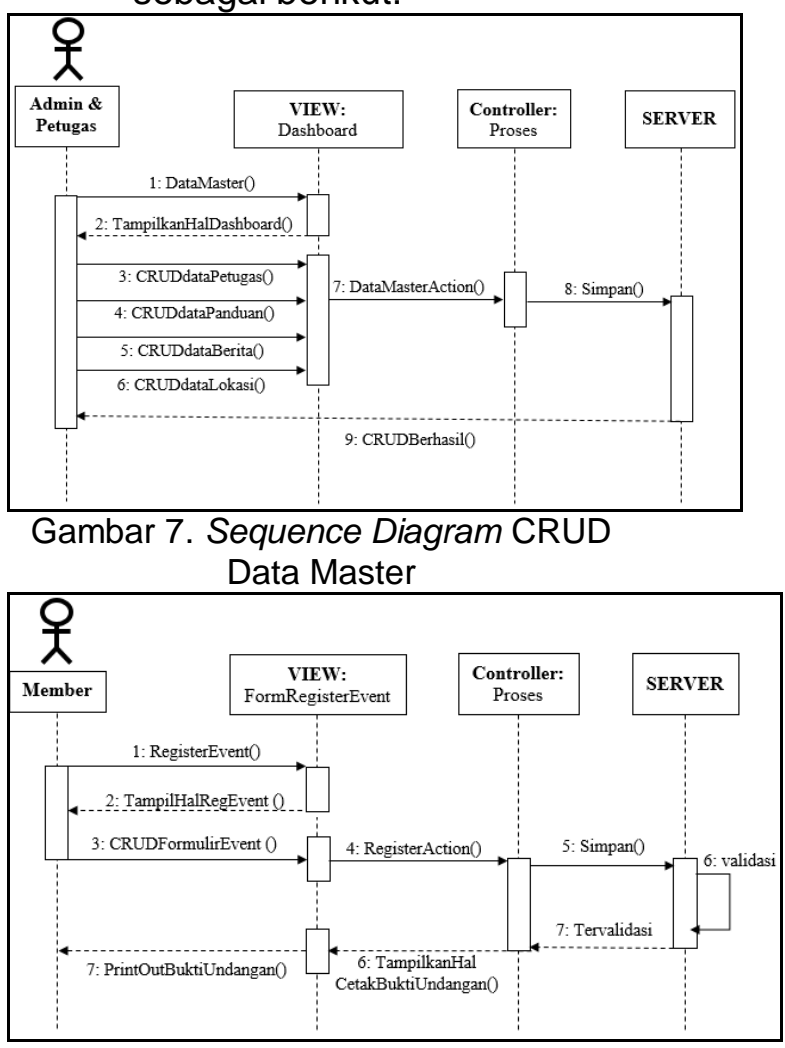

Gambar 8. Sequence Diagram Pendaftaran Event

e. Class Diagram

Menurut Hamim Tohari (2014:83) Kelas (Class) adalah sebuah spesifikasi yang jika diinstansiasi akan menghasilkan sebuah objek dan merupakan inti dari pengembangan dan perancangan berorientasi objek. Kelas menggambarkan keadaan (atribut/ properti) suatu sistem, sekaligus menawarkan layanan untuk memanipulasi keadaan tersebut (metode/fungsi). 


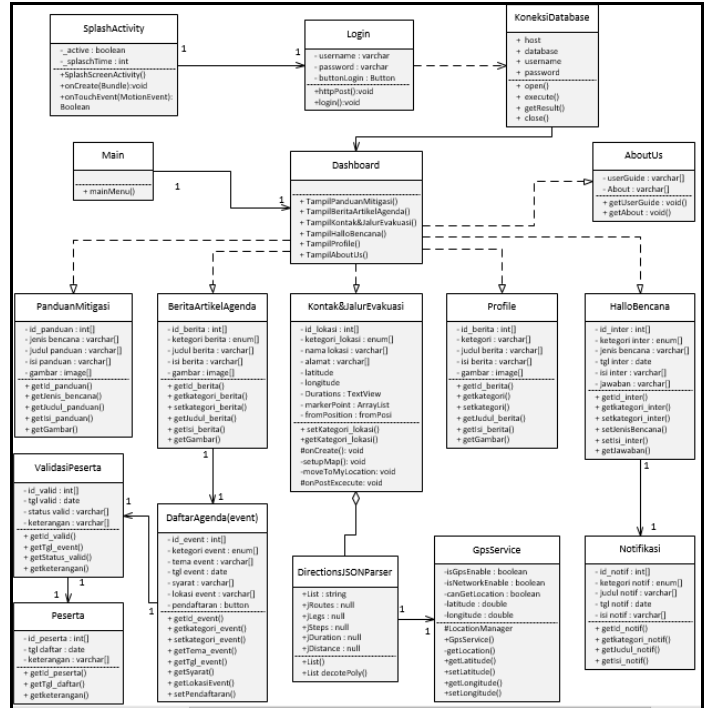

Gambar 9. Class Diagram

\section{f. Component Diagram} Component Diagram menunjuk-kan struktur dan hubungan antar komponen software termasuk ketergantungan (dependancy) antara komponen-komponen tersebut. Berikut adalah rancagannya.

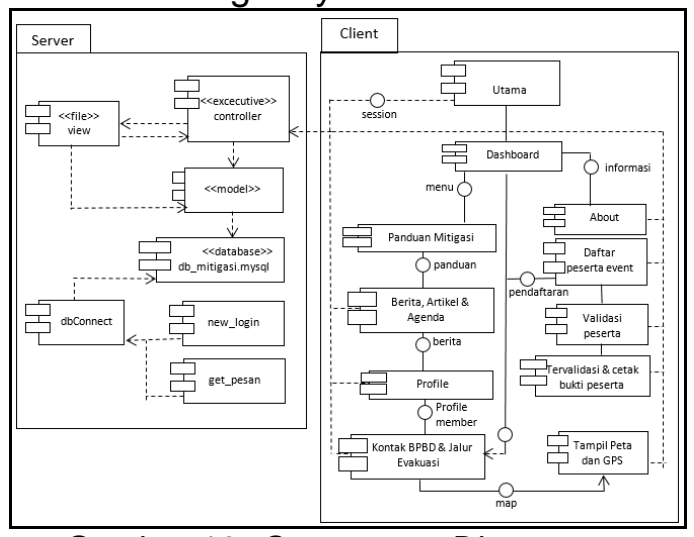

Gambar 10. Component Diagram

\section{g. Collaboration Diagram} Collaboration diagram berfungsi menggambarkan pengorganisasian interaksi yang terdapat disekitar objek dan hubungannya terhadap yang lainnya. Berikut ini adalah perancangannya pada server dan client.

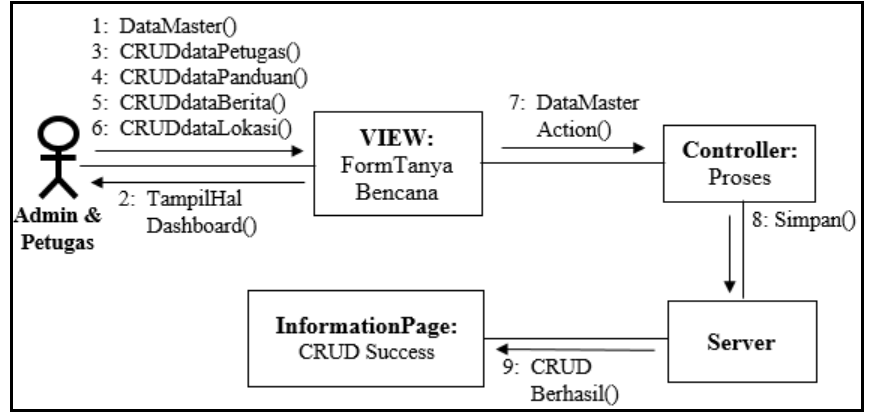

Gambar 11. Collaboration Diagram CRUD Data

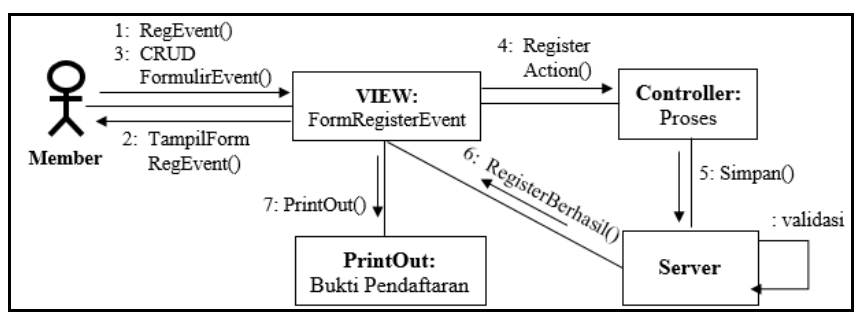

Gambar 12. Collaboration Diagram Pendaftaran Event

\section{h. Deployment Diagram}

Deployment Diagram menunjuk-kan pandangan secara fisik dari suatu sistem tentang bagaimana sistem diimplementasikan diperangkat nyata. Deployment Diagram menampilkan semua node dalam suatu jaringan dan hubungan di antara mereka. Node adalah perangkat keras yang dapat menjadi host dari suatu aplikasi. Berikut ini adalah perancangannya:

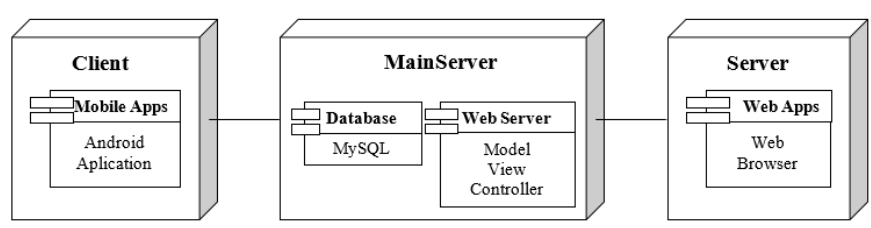

Gambar 13. Deployment Diagram

\section{Perancangan Basis Data}

Perancangan basis data merupakan upaya untuk membangun sebuah basis data dalam suatu lingkungan bisnis. Untuk membangunnya terdapat tahapan-tahapan normalisasi, seperti perancangan 
struktur tabel dan perancangan entity relationship diagram (ERD). Berikut ini adalah gambar perancangan ERD:

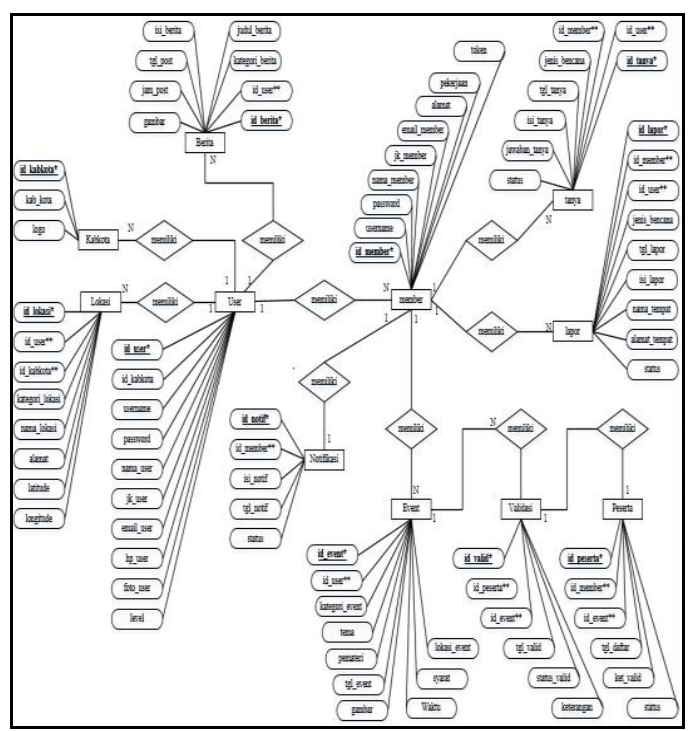

Gambar 14. ERD pada sistem

\section{Perancangan Interface}

Perancangan interface ini bertujuan untuk merencanakan interface yang akan digunakan pada sistem yang akan dibangun. Perancangan interface dibagi menjadi tiga (3) bagian yaitu rancangan input, rancangan output dan rancangan interface lainnya.

a. Interface Input Server Halaman ini akan muncul ketika user Petugas ingin menginputkan data Berita \& Artikel. Berikut adalah rancangannya.

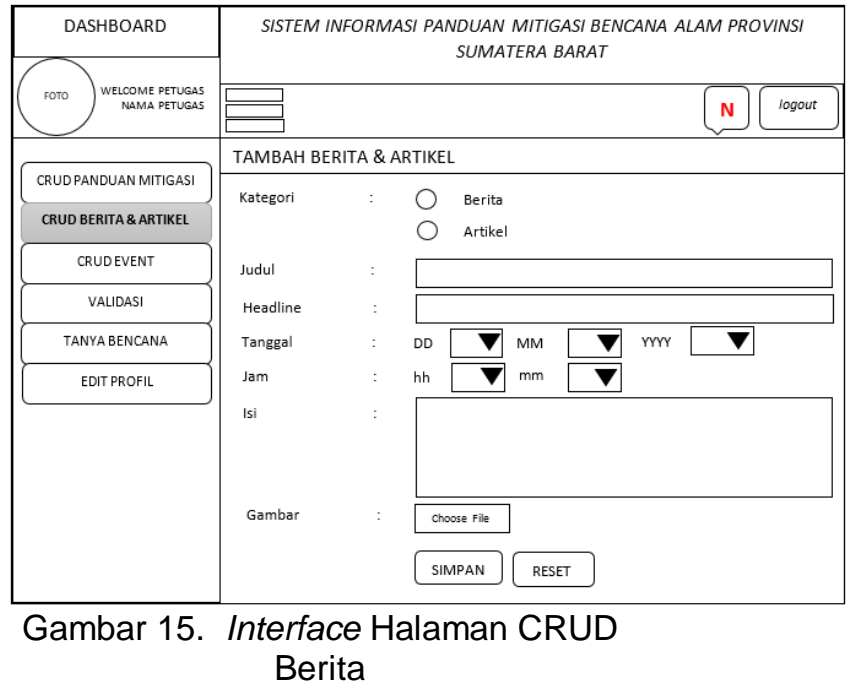

b. Interface Input Client tampilan Merupakan rancangan pendaftaran viewer/public yang ingin menjadi member. Berikut adalah rancangan interface halaman register:

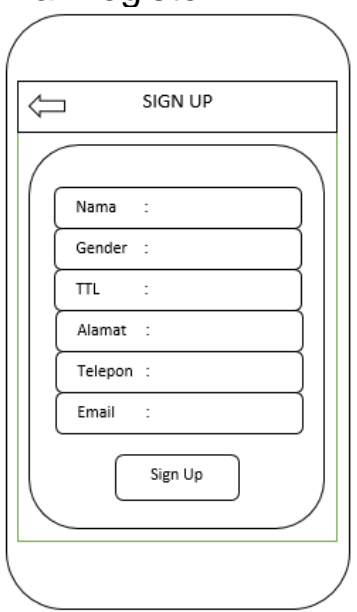

Gambar 16. Interface Register Member

c. Interface Output Server

Halaman ini merupakan halaman yang akan muncul ketika Petugas telah berhasil login pada website. 


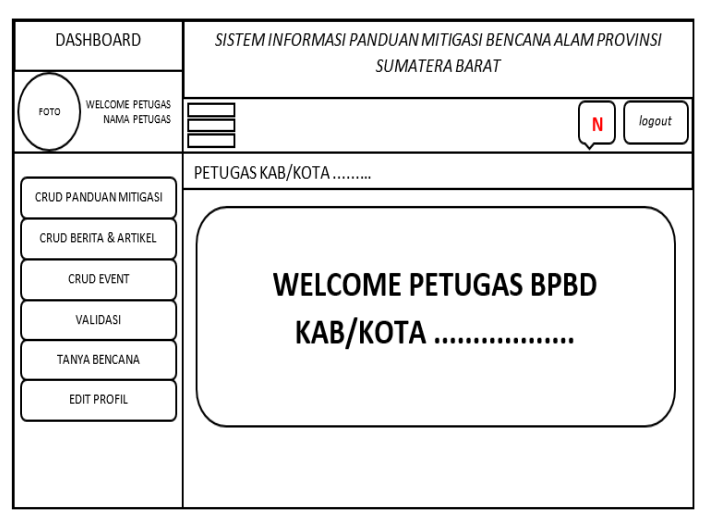

Gambar 17. Interface Halaman Petugas

\section{d. Interface Output Client}

Perancangan menu utama merupakan rancangan tampilan awal setelah tampilan splash screen. Berikut adalah interface menu utama Member.

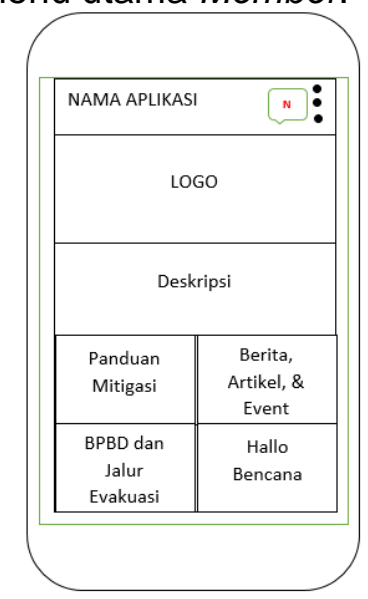

Gambar 18. Interface Menu Utama Member

5. Perancangan Sistem

Pada sistem ini

menggunakan teknik keamanan sistem seperti berikut :
a. Perancangan

Keamanan Enkripsi Data b. Perancangan Keamanan Session

Perancangan teknik keamanan session dapat dilihat pada gambar 22 berikut ini, sistem akan menampilkan data berdasarkan session level pengguna. Jika session level = Administrator, tampilkan halaman Administrator, jika session level = Operator (Petugas), tampilkan halaman Operator (Petugas).

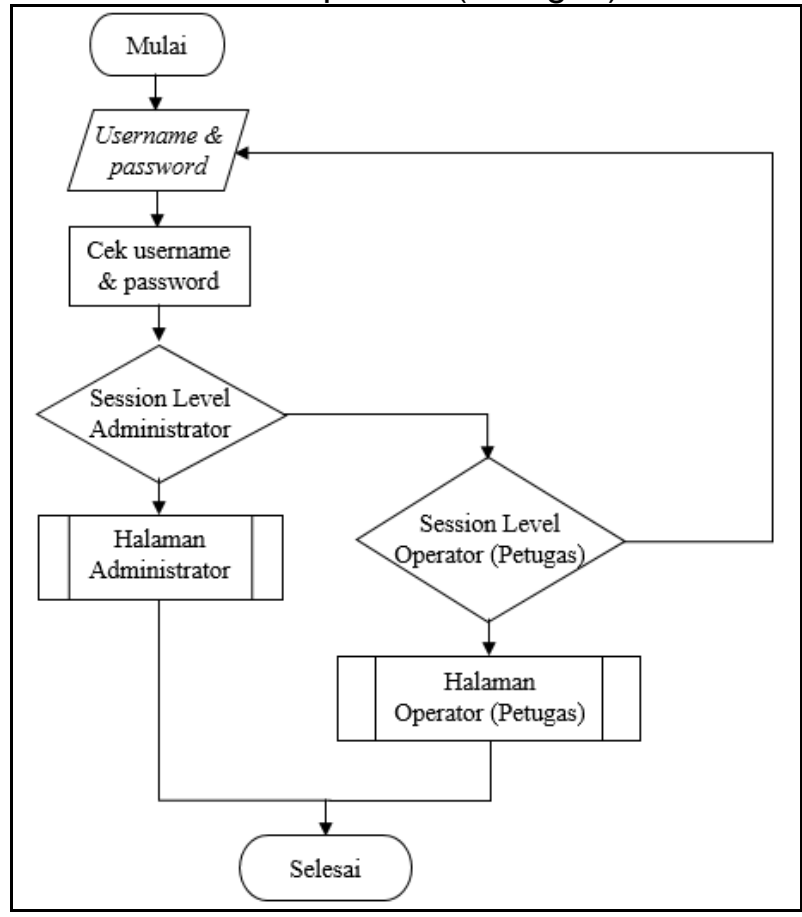

Gambar 22. Teknik Keamanan Session

\section{Perancangan Peta Situs (Site} map)

Perancangan peta situs (site map) merupakan desain yang menjelaskan navigasi pada sistem aplikasi yang akan dirancang. Masing-masing aktor memiliki hak dan kewenangan mengakses sistem yang berbeda-beda sesuai dengan levelnya. Terdapat dua buah aplikasi yaitu aplikasi pada sisi server yang diakses oleh user admin dan petugas, lalu aplikasi pada sisi client yang diakses oleh user member. Untuk lebih 
memahami alur berjalannya sistem aplikasi maka dapat dilihat sebagai berikut:

a. Administrator

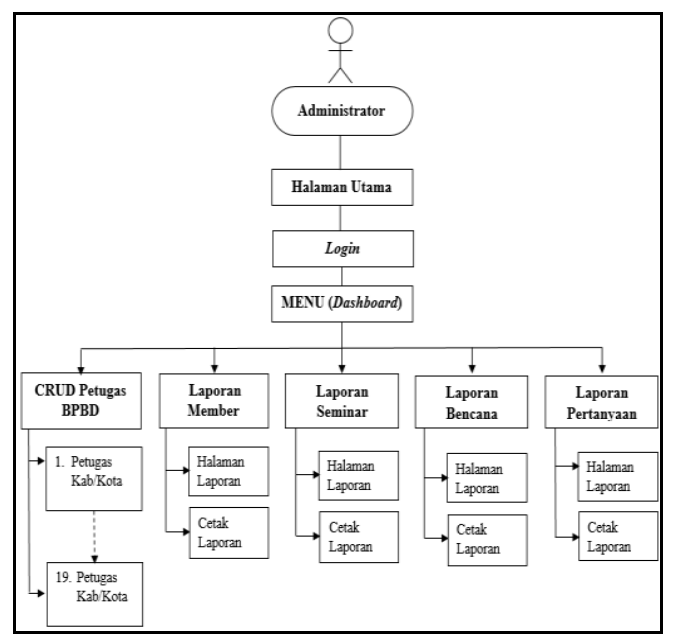

Gambar 23. Peta Situs (site map) Administrator

b. Petugas

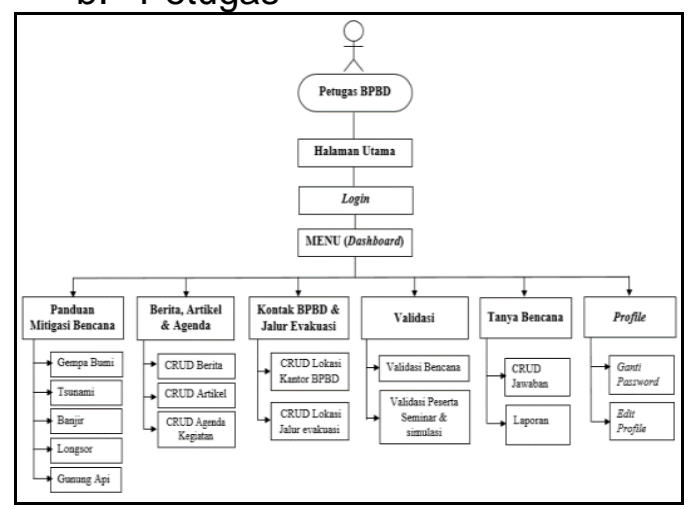

Gambar 24. Peta Situs (site map) Petugas

c. Member

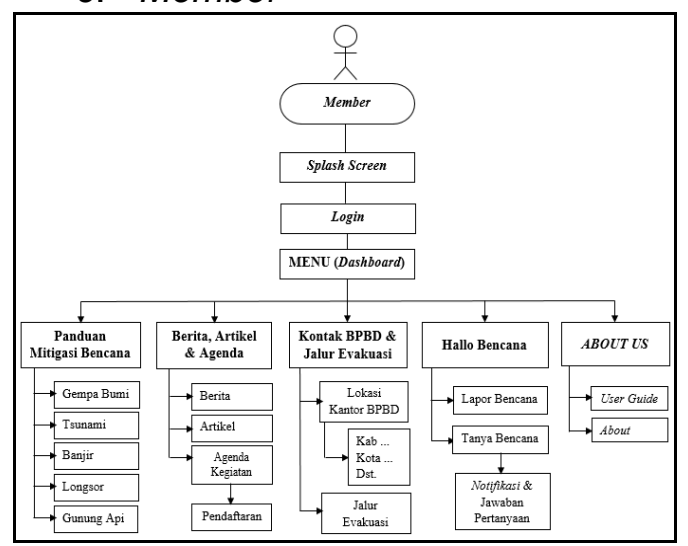

Gambar 25. Peta Situs (site map) Member

\section{HASIL DAN PEMBAHASAN}

Aplikasi Sistem Informasi Mitigasi Bencana Alam berbasis Android ini dirancang sehingga bisa digunakan pada sistem operasi Android dengan build target Android API (Application Programming Interface) minimal versi 22 atau 5.0 (Lolipop) sampai dengan Android versi terbaru saat ini.

\section{Interface pada Server}

Interface pada server merupakan interface yang dapat dilihat oleh Admin dan Operator melalui website menggunakan perangkat komputer.

a. Halaman Administrator Interface user Admin merupakan halaman yang dapat dilihat oleh user Admin berdasarkan level pada saat memasukkan username dan password pada halaman login.

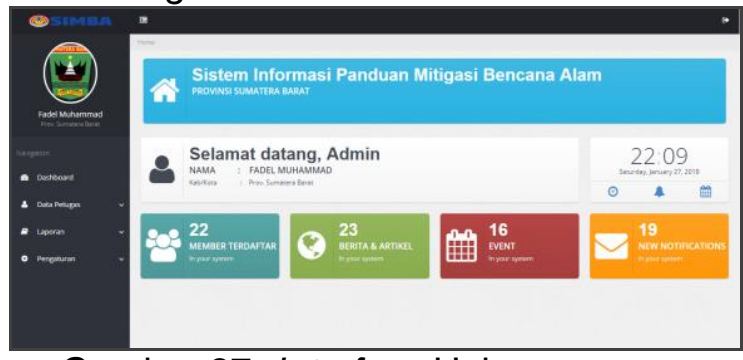

Gambar 27. Interface Halaman Utama Administrator

b. Halaman Petugas

$$
\text { Interface Petugas }
$$

merupakan halaman akses Petugas sebagai operator ditiap BPBD Kab/Kota. Sebagai Petugas, sistem dapat diakses untuk mengelola data berita, artikel event, lokasi, dan hallobencana. 


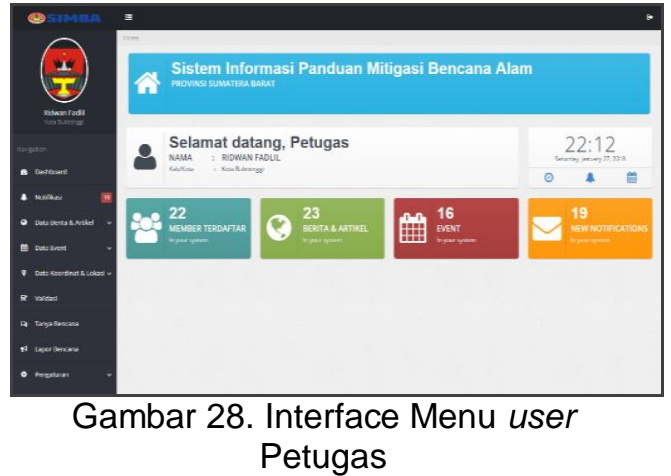

c. Halaman Notifikasi Server Halaman Notifikasi Server merupakan halaman Petugas yang dapat melihat pemberitahuan terbaru dari aktivitas client. Pemberitahuan yang diberikan dari client ke server antara lain bila ada laporan bencana, pertanyaan bencana dan pendaftaran event.

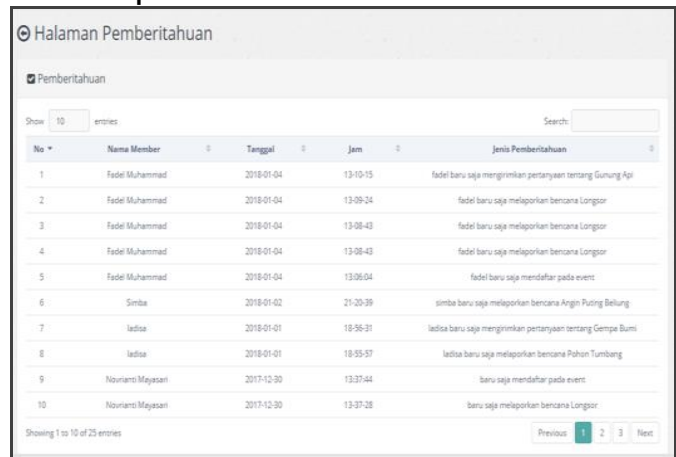

Gambar 29. Interface Halaman Notifikasi Server

d. Halaman Validasi Halaman validasi merupakan halaman yang digunakan untuk memvalidasi pendaftaran peserta pada sebuah event .

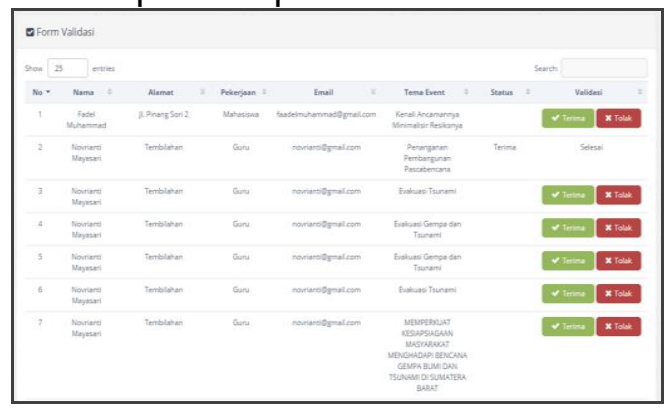

Gambar 30. Interface Halaman Validasi e. Halaman Tanya bencana Halaman Tanya bencana merupakan halaman yang digunakan untuk melihat pertanyaan member dan menjawab pertanyaan tersebut.

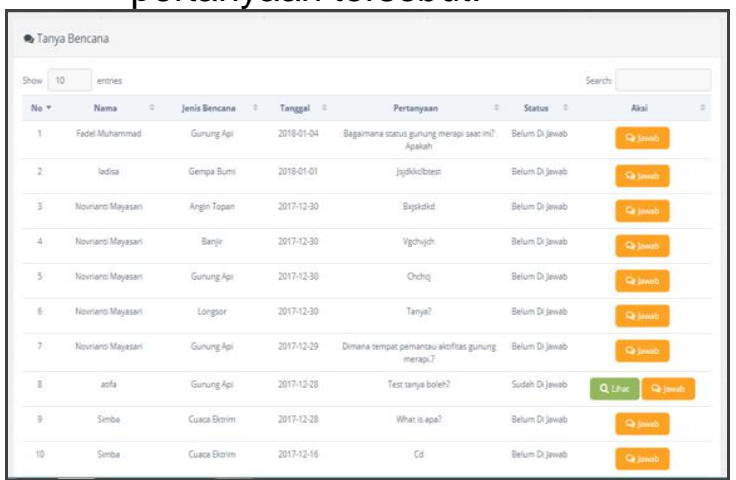

Gambar 31. Interface Halaman Tanya Bencana

f. Halaman Lapor Bencana Halaman Lapor bencana merupakan halaman yang digunakan petugas untuk melihat dan memvalidasi laporan yang dikirimkan oleh member.

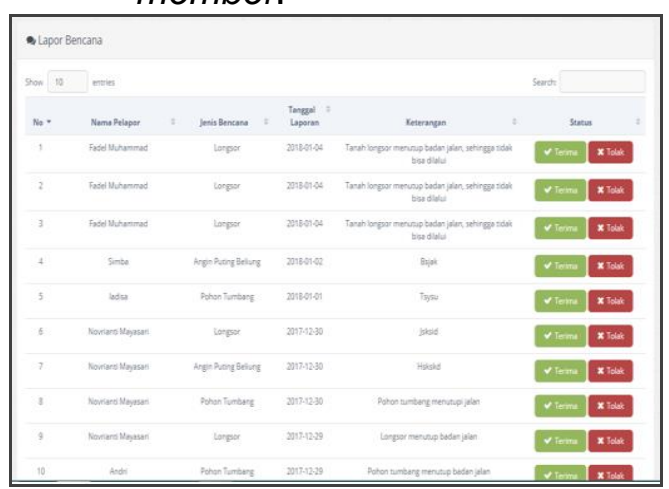

Gambar 32. Interface Halaman Lapor Bencana

g. Halaman Laporan Halaman laporan merupakan halaman yang menampilkan laporan output dari sistem. Seperti laporan member, event, peserta event, lapor bencana, tanya bencana. Laporan dapat dalam bentuk pdf, xls dan doc. 


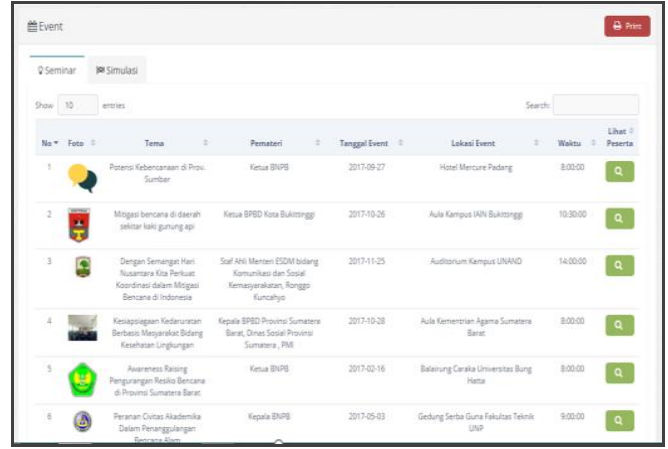

Gambar 33. Interface Halaman Laporan

h. Halaman Cetak

Halaman cetak laporan merupakan halaman yang dapat mencetak beberapa laporan seperti Laporan Member, Event, Peserta Event, Lapor Bencana, dan Lapor Bencana, dengan mengklik button print pada panel kanan atas dari tabel laporan.

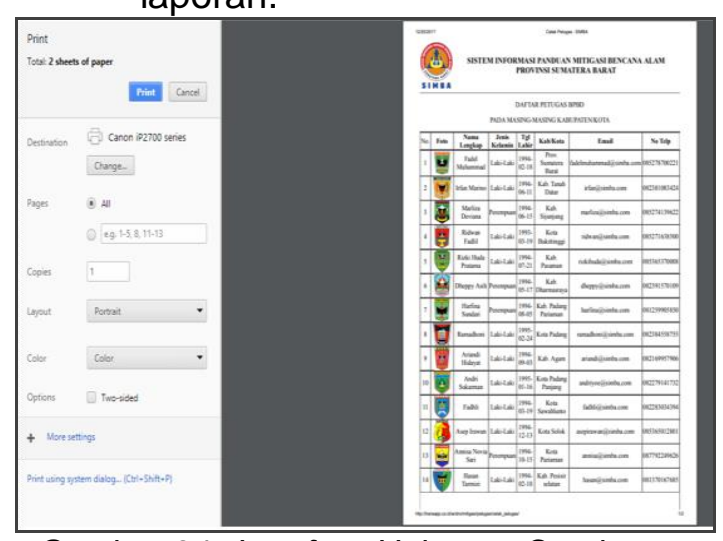

Gambar 34. Interface Halaman Cetak Laporan

\section{Interface pada Client}

Interface pada client merupakan interface yang dapat dilihat oleh Pengguna maupun member melalui aplikasi smartphone yang menggunakan sistem operasi Android.

a. Menu Utama

Interface halaman menu utama merupakan halaman aplikasi yang muncul setelah user melakukan login.

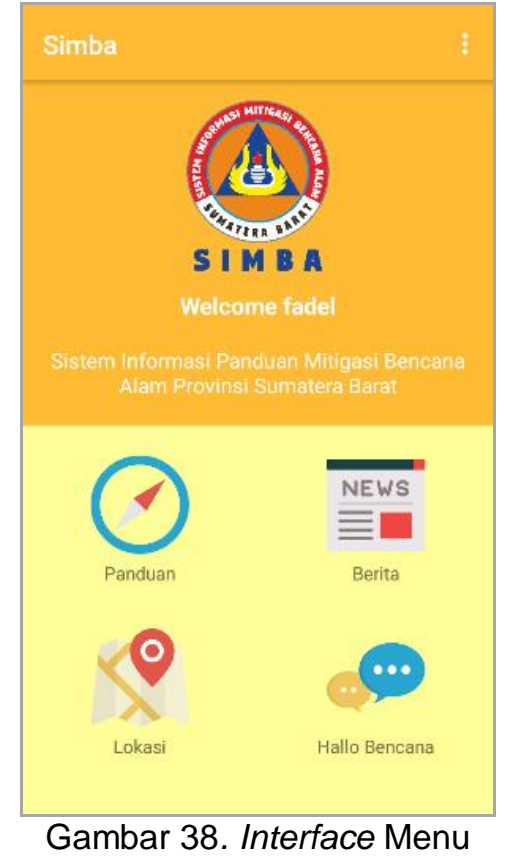

Utama

b. Panduan Mitigasi Interface menu

Panduan Mitigasi merupakan halaman untuk melihat panduan mitigasi

Pempa bumi terjadi karena gesekan antar
lempeng-lempeng tektonik di bawah
permukaan bumi Pergesekan ini
mengeluarkan energi yang luar biasa besar
dan menimbulkan goncangan di permukaan.
Indonesla sangat rawan gempa karena
secara geografi berada dekat dengan
lempeng-lempeng yang aktif dan saling
berhubungan satu sama lain, serta karena
adanya gunung-gunung api yang juga aktif.
A. Tindakan kesiapsiagaan
Merencanakan keslapslagaan terhadap
bencana tidak hanya mencakup perencanaan
fisik bangunan belaka. Setiap orang dalam
rumah sebalknya tahu apa yang harus
dilakukan dan ke mana harus pergi bila
situasi darurat terjadi. Berikut ini adalah
prinsip rencana kesiapsiagaan untuk rumah
tangga, diantaranya adalah:
1. Sederhana - Rencana darurat rumah
tangga dibuat sederhana sehingga mudah
diingat oleh seluruh anggota keluarga.
Bencana adalah situasi yang sangat
mencekam sehingga mudah mencetus
t..

Gambar 39 . Interface Panduan Mitigasi

c. Berita

Interface

Berita merupakan halaman untuk 
melihat berita yang berasal dari website BNPB.

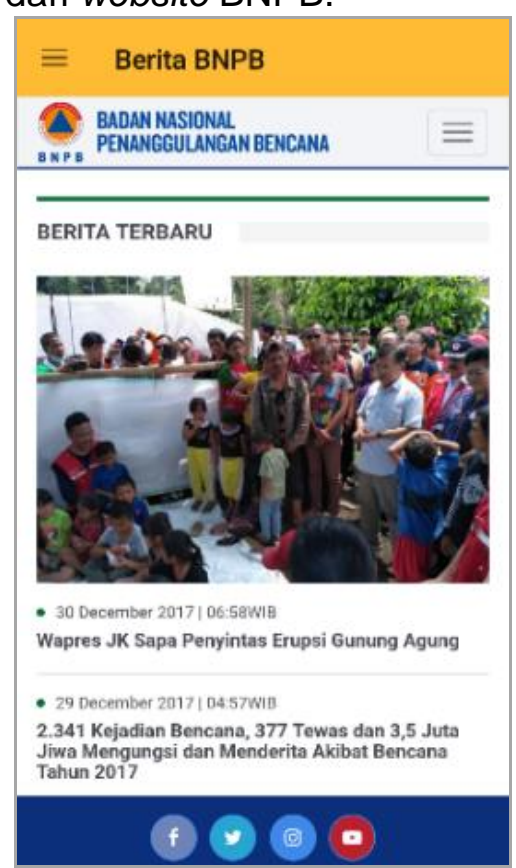

Gambar 40. Interface Berita

d. List Berita dan Event Interface List Berita \& Event merupakan halaman untuk melihat berita dan event yang berasal dari server yang di posting oleh petugas.

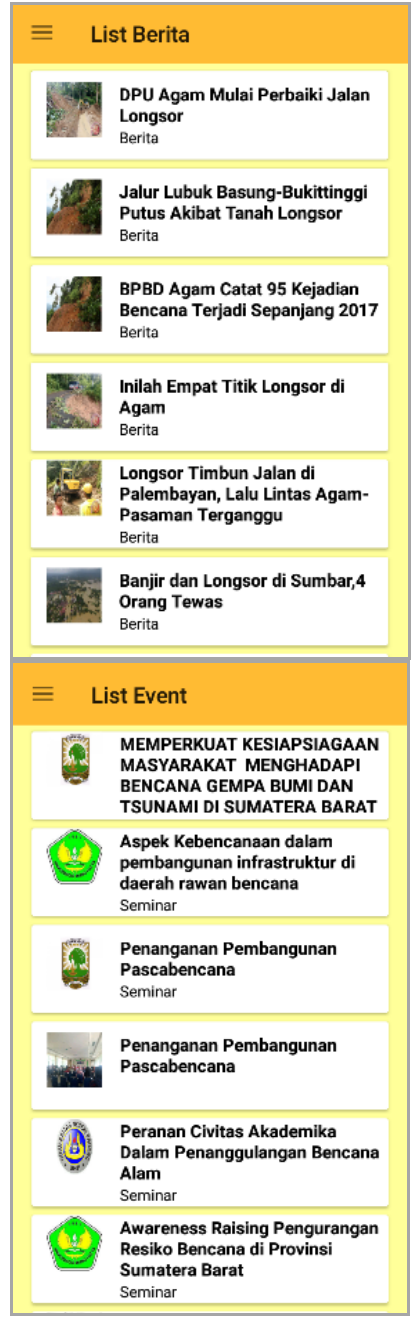

Gambar 41. Interface List Berita \& Event

e. Tampil Berita dan Event Interface Tampil Berita \& Event merupakan halaman untuk melihat berita dan event yang berasal dari server yang di posting oleh petugas. 


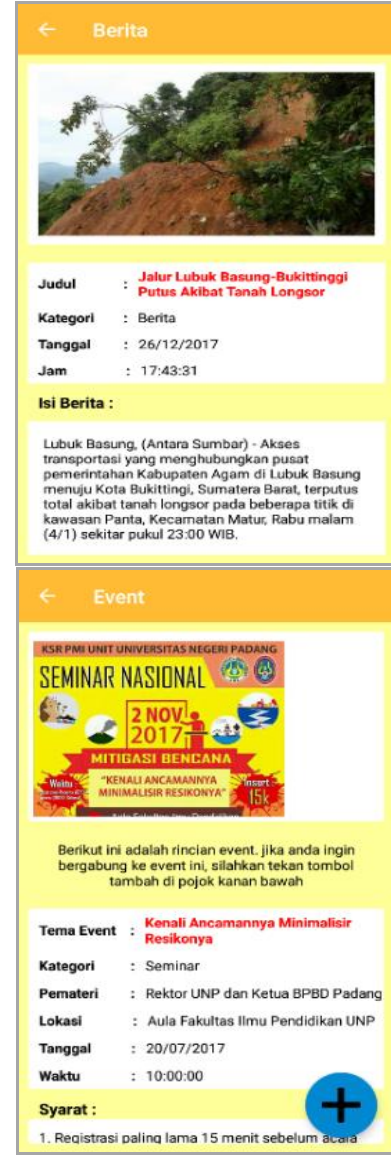

Gambar 42. Interface Tampil Berita \& Event

f. Daftar Event Interface halaman Daftar Event merupakan halaman untuk melakukan pendaftaran pada sebuah event,

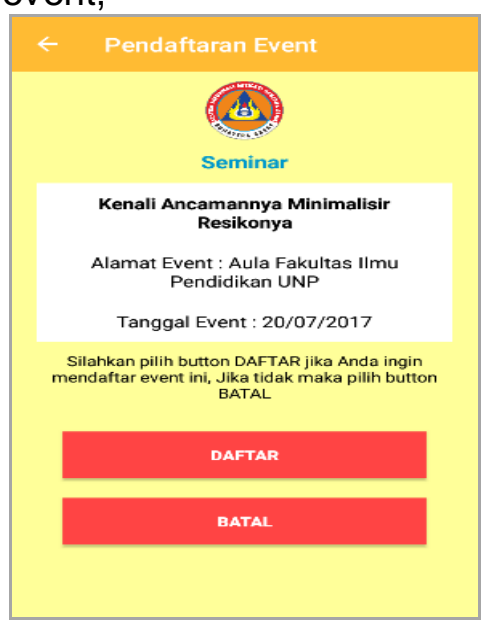

Gambar 43. Interface Daftar Event g. List Lokasi

Interface

yang

menampilkan daftar lokasi yang apabila salah satu dipilih maka akan berpindah ke halaman profil lokasi yang menampilkan detail lokasi.

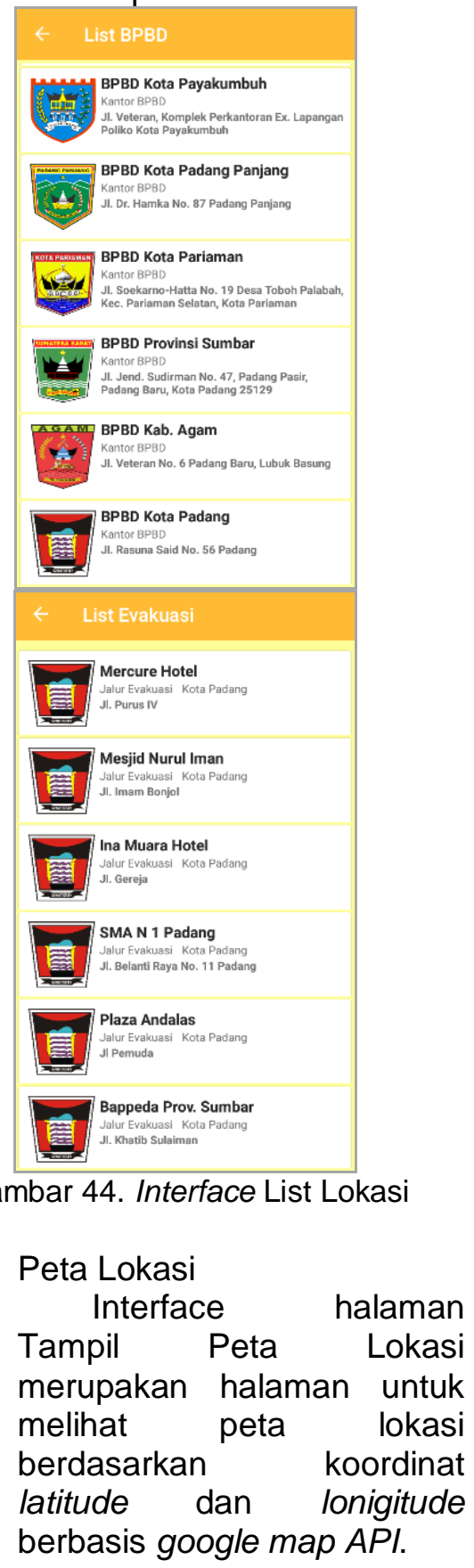




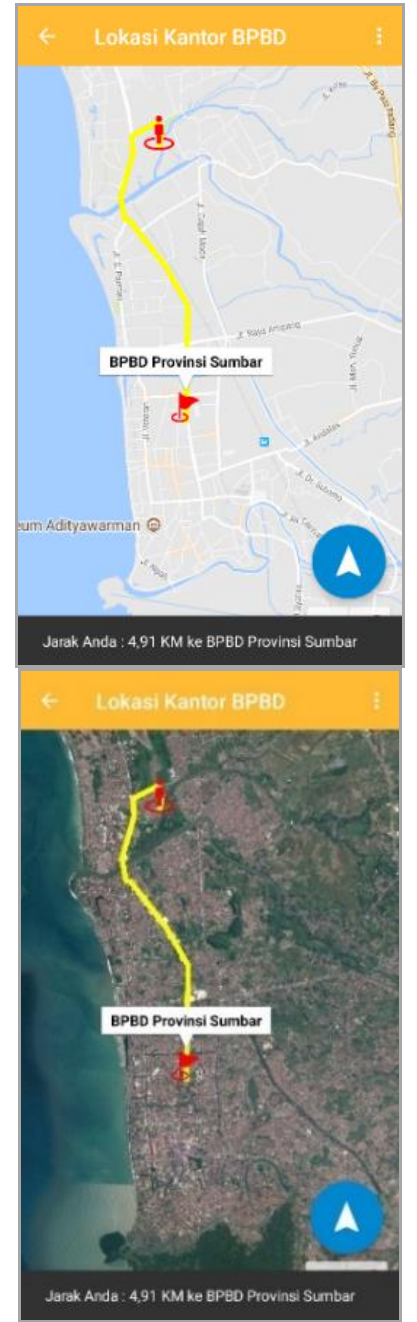

Gambar 45. Interface Peta Lokasi

\section{i. Tanya Bencana} Interface

Bencana

Lapor halaman untuk menginputkan jenis bencana, nama tempat, alamat tempat dan isi laporan yang akan dikirimkan ke server.

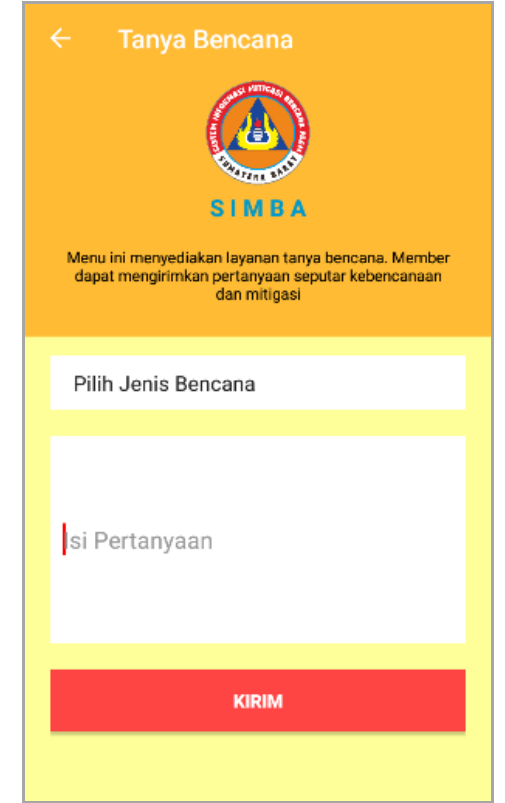

Gambar 46. Interface Tanya Bencana

j. Lapor Bencana Interface Tanya Bencana merupakan halaman untuk menginputkan jenis bencana dan isi pertanyaan yang akan dikirimkan ke server.

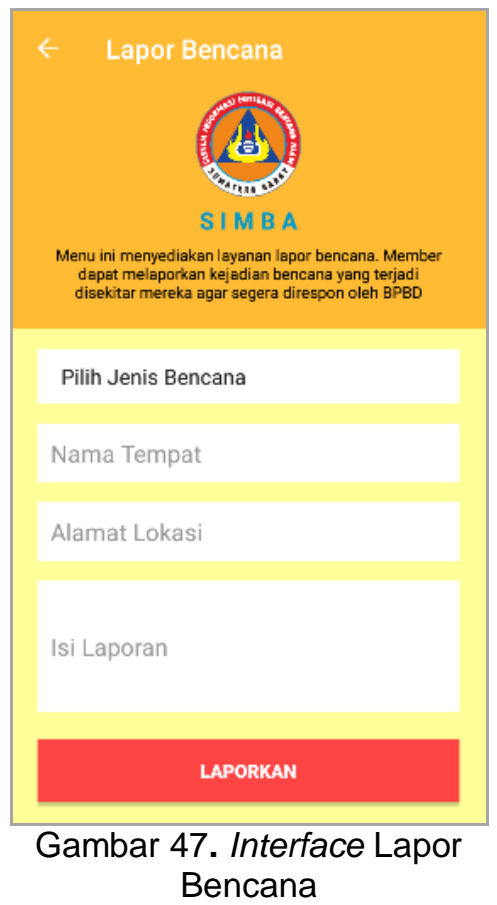

Bencana 


\section{KESIMPULAN}

Berdasarkan hasil Pengembangan Sistem Informasi ini dapat disimpulkan sebagai berikut:

1. Dengan pemanfaatan bahasa pemrograman PHP menggunakan framework Codeigniter pada pengembangan server dan bahasa pemrograman java pada pengembangan client dapat dikembangkan sebuah Sistem Informasi Panduan Mitigasi Bencana Alam Provinsi Sumatera Barat.

2. Dengan adanya Sistem ini, dapat membantu sekaligus mengedukasi masyarakat dalam hal panduan mitigasi bencana, berita, artikel, event seputar mitigasi dan layanan interaksi Lapor Bencana \& Tanya Bencana serta memberikan peta petunjuk lokasi BPBD dan Jalur evakuasi.

3. Dengan pemanfaatan teknologi website pada aplikasi server dan platform Android sebagai aplikasi client, kita dapat menerapkan sebuah paradigma Client-Server pada pengembangan aplikasi.

\section{SARAN}

Adapun saran yang diberikan setelah mengembangkan Sistem Informasi ini antara lain:

a. Diharapkan Sistem Informasi ini dapat digunakan sebagai bahan referensi bagi pengembang sistem informasi (IT developer) untuk pengembangan aplikasi selanjutnya.

b. Diharapkan Sistem Informasi ini dapat digunakan sebagai bahan referensi dan tambahan informasi bagi Pihak yang terkait maupun tidak terkait untuk pengkajian topik yang berkaitan dengan masalah yang sama dan dapat digunakan sebagaimana mestinya.

c. Masyarakat dapat memanfaatkan aplikasi ini sebagai media untuk mendapatkan informasi panduan mitigasi, berita, artikel \& event dan peta petunjuk lokasi BPBD \& jalur evakuasi bencana di wilayah Provinsi Sumatera Barat.

d. Pemerintah dan BNPB/BPBD Provinsi Sumatera Barat dapat memanfaatkan sistem ini sebagai media untuk mensosialisasikan informasi panduan mitigasi, berita artikel \& event mitigasi, dan peta petunjuk lokasi BPBD \& jalur evakuasi bencana sebagai upaya pencegahan, kesiapsiagaan guna mengurangi dan menimimalisir risiko yang ditimbulkan oleh bencana.

\section{DAFTAR PUSTAKA}

[1] Abdul Kadir. (2014). Pengenalan Sistem Informasi Edisi Revisi. Yogyakarta: Andi.

[2] BNPB. (2013). Indeks Risiko Bencana Indonesia (IRBI). Jawa Barat: BNPB

[3] BNPB. (2016). Penurunan Indeks Risiko Bencana Indonesia (PIRBI). Jawa Barat: BNPB

[4] Hamim Tohari. (2014). Astah (Analisis serta Perancangan Sistem Informasi melalui pendekatan UML). Yogyakarta: Andi.

[5] Syafendri Deputra. (2015). Rancang Bangun Aplikasi Jalur Evakuasi Tsunami Kota Padang Berbasis Mobile Pada Sistem Operasi Android. Tugas Akhir. Universitas Negeri Padang. 